\title{
Career Decision Regret as a Predictor: Do Teachers and Administrators Regret Due to Their Career Choice?
}

\author{
Akif Köse ${ }^{1, *}$ \\ ${ }^{1}$ Educational Sciences Department, Faculty of Education, Kahramanmaraş Sütçü İmam University, Kahramanmaraş, \\ Turkey \\ *Correspondence: Educational Sciences Department, Faculty of Education, Kahramanmaraş Sütçü İmam University, \\ Kahramanmaraş, Turkey. Tel: 90-344-300-4433. E-mail: akifkose44@gmail.com
}

Received: December 13, 2018

Accepted: January 2, 2019 Online Published: January 21, 2019

doi:10.5430/wje.v9n1p38

URL: https://doi.org/10.5430/wje.v9n1p38

\begin{abstract}
This research aims to explore the relationship between career decision regret, job satisfaction and life satisfaction as well as determining whether career decision regret significantly predicts job satisfaction and life satisfaction. Having a descriptive research design, the research has employed relational survey model. The population of the research holds a total of 7671 teachers and administrators who work at pre-school education institutions, primary, secondary and high schools located within the central provinces of Kahramanmaraş. The research sample consists of 365 participants who have been selected through a random sampling method. The research has deployed "Career Decision Regret Scale", "Job Satisfaction Scale" and "Satisfaction with Life Scale". Independent groups t-test, one-way ANOVA test, Pearson correlation and regression analysis have been used during data analysis. Research results have revealed that teachers' and school administrators' career decision regret is at "a little" level; they have experienced a medium level of general, intrinsic and extrinsic satisfaction; they are at the level of "neither agree nor disagree" in terms of life satisfaction; there is a negative and medium level relation between career decision regret and life satisfaction and between career decision regret and job satisfaction; a significant, positive and medium level relation between job satisfaction and life satisfaction; career decision regret is a significant predictor of job satisfaction and life satisfaction; $25 \%$ of the total variance of job satisfaction and $22 \%$ of the total variance of life satisfaction level of teachers are explained by career decision regret.
\end{abstract}

Keywords: career decision regret, job satisfaction, life satisfaction

\section{Introduction}

Decision can be defined as the act of choosing the most suitable one or ones among certain options. It can also be explained as the determination and use of the most appropriate possible solutions towards a problem. These definitions reveal that decision is the process of passing judgment. The fact that individuals have to constantly decide both in their private lives and in their business life shows they are required to make a judgment regarding certain issues throughout their lives. Decision making is an indispensable part of human life and is a phenomenon that exists at every moment of life as individuals make decisions about many subjects such as the choice of food, home, parent and friends as well as their profession (Çakır, 2004).

It is an inevitable condition for individuals and institutions that those who have acquired certain professional qualifications must make various decisions in their professional practices. This is also the case for teachers, administrators and students working at educational organizations. A teacher has to take various pedagogical decisions within a class hour. That a student is interested in the lesson and pays attention to it is also a kind of decision making. Making decisions for a school administrator is an indispensable process for management since decision-making is the heart of management (Bursalıoğlu, 2012).

Educational organizations are decision-making organizations in which decisions are taken and implemented consistently. Educational organizations constantly make decisions due to the high number of people in these organizations (Şahin \& Ada, 2013). Service is produced by people in educational organizations. In particular, students and their families are affected by the produced service along with the society itself in general, and 
universally all humans. In this regard, it is an undeniable fact that education service and each person to whom this service is provided is significant. Even though man is only a moment of universal time and temporary guest of the world, s/he is the trace of his/her species, the scion of the race, the combination of the body, mind and personality, the member of family and society, the passenger or inquisitor of the faith path, the worker of the economy, the citizen of the government and the warrior of the army (Durant \& Durant, 1968; Güvenç, 1992).

Taking a serious decision just as becoming a teacher to undertake the task of educating this important entity called human being requires to have a goal, to be full of courage and human love and to envisage the constant development and certain difficulties. On that point, a deliberate decision provides serious clues regarding the quality of future educational services. However, as in every profession, the decisions of the individuals who have chosen teaching profession may not always be conscious, or they may be taken due to certain obligations. The type and level of the assumptions and requirements during the decision process are considerable indicators of the quality of the future teaching profession.

Career choice is a significant turning point for an individual's life, and most likely one of the most important choices. During career choice, an individual chooses a certain type of work and lifestyle for himself/herself, tries to successfully prove himself/herself on this path, and determines his/her future life (Çakır, 2004, Sarıkaya \& Khorshid, 2009). Career choice is an issue that should be emphasized in planning an individual's life career as the possible consequences of inconvenience in later periods will directly affect the life of the individual if the individual's career choice is not made in accordance with his/her life preferences (Öztemel, 2012).

When it comes time to put a profession choice into practice, some individuals may be unstable due to lack of information about their professions, pressure from other people who are respected, and some nonfunctional thoughts (Çakır, 2004) or they may make wrong decisions at the point of career choice in case of the lack of information regarding their demographic characteristics. Moreover, there are various reasons that negatively affect decisions during the process of choosing a profession. The agitations and conflicts that individuals have experienced in their inner world, the inability of individuals to be aware of the competencies they hold and those required by their profession due to their inadequate knowledge about themselves, the inadequacy of information about the profession and the field of education, the presence of misguided beliefs experienced in previous life as well as experiencing ambiguity, that is external conflicts, by failing to reconcile the demands of family members and other individuals who are important for them can be expressed as the reasons which affect negatively the individual's decision to choose a profession (Çakır, 2004). The lessening of these reasons or the individual's choice of profession independently of these reasons may prevent or reduce the proportion of future regrets regarding career choice in advance. The individual becomes successful, productive and happy in his/her profession preferred in accordance with his/her talents, interests and desires; in contrast, s/he becomes unsuccessful, unproductive and unhappy when s/he makes random choices without considering the characteristics. Therefore, what is ideal is to make a career choice in accordance with the individual's interests and abilities (Sarıkaya \& Khorshid, 2009). A choice made in this way may only hamper career decision regret, or it may reduce the amount of regret.

The individual will spend a significant part of his/her life in his/her profession. S/He spends his/her time in the business environment to perform his/her occupation instead of his/her family and relatives. In this respect, career decision regret negatively affects his/her life and profession. Job satisfaction and life satisfaction may be mentioned as the leading factors that will be affected by career decision regret of the individual since it may cause the individual to perceive the living conditions negatively, which leads to a decrease in life satisfaction and inability to have job satisfaction.

Job satisfaction which is affected by the individual's career decision regret may be defined as "Satisfaction of the worker when the expected and the realized are considered as equal to each other" (Demirtaş \& Güneş, 2002) and "Pleasure of the worker as a result of evaluating all working conditions". This level of pleasure is proportional to the relation between the work of the employee and the expectations of the institution. The common point of the definitions related to job satisfaction is the harmony between the expectations of the employees from the workplace and the things they get and it is sense of emotion felt by the employee when $\mathrm{s} / \mathrm{he}$ is compatible with the values in the organization (Özben \& Argun, 2005) and satisfaction experience by the employees when their expectations and the things presented by the organization are compatible with each other (İnce \& Şahin, 2016).

Job satisfaction is a desired phenomenon in terms of both individuals and organizations. Educational organizations in which service is provided by humans want teachers and administrators to satisfy with their jobs. Job satisfaction is related to the fact that teachers must successfully fulfil the duties and responsibilities (Gençtürk \& Memiş, 2010) since high level of teachers' job satisfaction is necessary for the high quality of education. 
There are various factors determining the existence and level of job satisfaction. Balc1 (1985) has noted that factors affecting job satisfaction can be grouped under two main headings: individual factors (age, gender, seniority, intelligence, educational level, sociocultural characteristics, and personality differences) and environmental factors (work, wage and promotion possibilities, colleagues and supervision) (Taşdan \& Tiryaki, 2008). Likewise, Gençtürk and Memiş (2010) have stated that job satisfaction of teachers is influenced by the external factors (gender, class levels, teachers' ages, salaries, professional experience, administrative relationships, internal-external awards, payments, social rights and work security) and internal factors (meeting the needs with high level such as self-esteem, feeling of success and personal development). Özben and Argun (2005) have emphasized that administrator and parent support, student behaviours, school atmosphere, teacher independence and working conditions affect teachers' job satisfaction. Yazilitaş (2010) has suggested that teachers' job satisfaction levels are influenced by gender and seniority factors. Teachers' job satisfaction is also associated with their performance, and that their performance is related to what extent teachers perceive themselves as sufficient to carry out this profession (Berkant, 2017). When assessed as a whole, individuals differ in their personality and demographics, their needs vary in type and level, and their socio-cultural and economic environment have different characteristics, which may affect both the quality and the quantity of their job satisfaction.

Job satisfaction of the employees is also closely related to their happiness and peacefulness in their work and their motivation. Particularly, teachers who are unhappy and unsatisfied may cause negative effects such as decreasing the performance and motivation of their colleagues in terms of the organization besides the unsatisfactory ones they experience in the individual sense (Özben \& Argun, 2005). Motivation, which has an important place in terms of organizations, can be defined as an intrinsic process that begins with the individual moving into action to achieve an aim. The reasons lying behind motives based on aims (physiological motives, social and psychological motives) and those based on sources (internal motives, external motives) (Sağır, 2016) are the existence of the individual's need, and the disturbance felt by this need, individual's ability to act and achieve satisfaction for eliminating this disturbance. When it comes to educational organizations, it can be expressed that teachers and administrators have some needs, that they have acted to meet these needs, and that they have achieved professional satisfaction in the organizational environment to the extent that these needs can be met.

If the needs of the individual are met at the workplace, it is not difficult for the individual to go to work, $\mathrm{s} / \mathrm{he}$ enjoys working at the workplace, and as a result, he or she fulfils the work most efficiently rather than considering it as a task. Thus, s/he becomes positive in his/her relationship with the effort to bring innovations (Koruklu, Feyzioğlu, Özenoğlu-Kiremit, \& Aladağ, 2013). Therefore, organizations need to pay great attention to the needs of their employees. Because the potential motivation tools of a job are considered to be signs of various work-related outcomes (Ayan, Kocacık, \& Karakuş, 2009). The relevant literature points out that the expectation of the individual's job fulfilment is positively influential on their morale, motivation and satisfaction, thus increasing the chances of individuals making more efforts and succeeding in their job (Kumaş \& Deniz, 2010). In this respect, it can be stated that there is a relation between motivation, job satisfaction and job quality (Ağırbaş, Çelik, \& Büyükkayıkçı, 2005; Köroğlu, 2011; Toker, 2006) and this relationship is of great importance for employees and organizations. Job satisfaction is sometimes a determinant of an important variable such as motivation, but it may sometimes serve as a variable that is influenced by motivation. However, it may be wise to mention that job satisfaction is also related to an important variable such as life satisfaction along with motivation. Within the scope of this research, life satisfaction, which is related to both job satisfaction and career decision regret, is emphasized with respect to today's organizations and examined intensively in terms of administration.

"Life satisfaction", which is a psychological feature of people's expectations of life and their level of satisfaction, has effects on the organizational life of employees (Recepoğlu, 2013), in this regard, life satisfaction of employees is taken care and considered by the organizations (Haybron, 2001). Life satisfaction, which has been the focus of humanity for centuries, is a cognitive component of subjective well-being and involves the cognitive appraisals of the individual's own life (Dağlı \& Baysal, 2016; Diener, 1984).

First introduced by Neugarten in 1961, life satisfaction refers to the result obtained by comparing a person's expectations (what $\mathrm{s} / \mathrm{he}$ wants) and his/her possessions (what $\mathrm{s} /$ he possesses) and expresses the situation that arises when a person's expectations are compared with the existing ones (Kırc1-Çevik \& Korkmaz, 2014; Özer \& Karabulut, 2003; Recepoğlu, 2013). Life satisfaction, which is the general evaluation of the quality of life based upon the criteria chosen by the individual, includes the present satisfying life, the fulfillment of the past, the fulfillment of the future, the desire to change life and the opinions of one's relatives about the life of himself/herself (Kırc1-Çevik \& Korkmaz, 2014). 
In general, life satisfaction which includes the entire life of the person and all dimensions of this life (Avşaroğlu, Deniz, \& Kahraman, 2005) consists of three parts. The first one defines the life of an individual as well-being by comparing it with external criteria. The second part is the sensory state of the individual judging his/her own life. The third one is the satisfaction resulting from daily relationships (Serin \& Özbulak, 2006, Recepoğlu, 2013).

Life satisfaction indicating a positive situation in terms of organizations and individuals is influenced by many factors which are freedom, democracy, open-mindedness and activeness, political stability, feeling that control of one's own life is in his/her own hands, being physically and spiritually healthy, being married, having good relations with friends and family, doing sports, living in a reliable region, having a wide social environment as well as having a positive individual identity (Dockery, 2004, Khakoo, 2004; Özdevecioğlu \& Aktaş, 2007). The level of the work-family conflict experienced by the individual and the state of being in harmony with the individual's family can also be expressed as other factors affecting life satisfaction (Özdevecioğlu \& Aktaş, 2007). The individual is influenced by his/her life outside his/her work life, and his working life is positively or negatively reflected in his/ her social life (Keser, 2005).

Life satisfaction may be closely related to the working life of individuals. However, it is also thought that there are different approaches to the relationship between job satisfaction and life satisfaction. These approaches stress that working life does not affect life satisfaction positively or negatively; life satisfaction affects the satisfaction obtained from working life; there is no relationship between these two concepts. What is certain is the existence of a strong relationship between working life and life satisfaction (Keser, 2005). In the process of nearly 30 years, a great number of researches have shown the effect of job satisfaction on the general life, attitudes and behaviours of the individual and life satisfaction (Kırc1-Çevik \& Korkmaz, 2014).

In addition to the relationship between life satisfaction and job satisfaction, which are important for individuals and organizations and which is conducted by many different researchers, exploring the relationship between these variables and career decision regret, and determining whether career decision regret predicts life satisfaction and job satisfaction, which will be presented for the first time in this research, are expected to contribute to the relevant literature and practitioners in this direction. In service of this goal, answers to the following questions have been sought:

1. What is the level of teachers' and school administrators' career decision regret, job satisfaction and life satisfaction?

2. Do teachers' and school administrators' views regarding career decision regret significantly vary across their gender, marital status, graduation status, institution type, seniority and job type?

3. Do teachers' and school administrators' views regarding job satisfaction significantly vary across their gender, marital status, graduation status, institution type, seniority and job type?

4. Do teachers' and school administrators' views regarding life satisfaction significantly vary across their gender, marital status, graduation status, institution type, seniority and job type?

5. Is there a significant relationship between career decision regret, job satisfaction and life satisfaction?

6. Does career decision regret significantly predict job satisfaction and life satisfaction?

\section{Method}

This section holds information regarding the research model, population and sample, data collection tools, data collection and analysis.

\subsection{Research Design}

Having a descriptive research design, this research has employed a relational survey model. Relational survey model is a research model that aims to determine whether there is a relationship between two or more variables, and if so, the level of the relationship (Karasar, 2014). This research has examined teachers' and school administrators' career decision regret, job satisfaction and life satisfaction levels in terms of several demographic characteristics. In addition, the research has also explored the relationship between teachers' and school administrators' career decision regret, job satisfaction and life satisfaction and the prediction level of career decision regret to the job satisfaction and life satisfaction.

\subsection{Population and Sample}

The population of the research holds a total of 7671 teachers and administrators (Onikişubat Province 4756; 
Dulkadiroğlu Province 2915) who work at pre-school education institutions, primary, secondary and high schools located within the central provinces of Kahramanmaraş (Onikişubat, Dulkadiroğlu) (https://dulkadiroglu.meb.gov.tr/, Access date: 26.02.2018; http://onikisubat.meb.gov.tr/, Access date: 26.02.2018). The research sample consisting of 365 participants has been determined to be sufficient ( $95 \%$ confidence interval).

Table 1 depicts demographic characteristics regarding participants.

Table 1. Frequency and Percentage Values Regarding Participants' Demographic Characteristics

\begin{tabular}{llll}
\hline Demographic Characteristics & & (f) & (\%) \\
\hline \multirow{2}{*}{ Gender } & Male & 189 & 51,8 \\
& Female & 176 & 48,2 \\
Marital Status & Single & 44 & 12,1 \\
& Married & 321 & 87,9 \\
Graduation Status & Undergraduate & 312 & 85,5 \\
& Postgraduate & 53 & 14,5 \\
Institution Type & Pre-school & 35 & 9,6 \\
& Primary school & 55 & 15,1 \\
& Secondary School & 127 & 34,8 \\
& High School & 148 & 40,5 \\
Seniority & 1-5 years & 57 & 15,6 \\
& 6-10 years & 69 & 18,9 \\
& 11-15 years & 83 & 22,8 \\
Job Title & 16-20 years & 69 & 18,9 \\
Total & 21 y1l and over & 87 & 23,8 \\
& Teacher & 316 & 86,6 \\
& School administrator & 49 & 13,4 \\
& & 365 & 100 \\
\hline
\end{tabular}

As shown in Table 1, the majority of the participants consists of those who are male, married, undergraduates, who work in high schools, who have " 21 years and over" working experience and who work as teachers.

\subsection{Data Collection Tools}

The research has deployed three data collection tools: "Career Decision Regret Scale" in order to determine teachers' and administrators' career decision regret; "Job Satisfaction Scale" to identify their job satisfaction levels; "Satisfaction with Life Scale" to determine their life satisfaction. Prior to collecting all research data, a preliminary implementation has been conducted with 128 participants and the reliability values of the scales have been examined as a result of this implementation, and the reliability levels of the scales have been determined as acceptable and then the actual implementation has been initiated. The data obtained from 128 participants during the preliminary practice have been evaluated together with the actual implementation data.

\subsubsection{Career Decision Regret Scale}

Career Decision Regret Scale consisting of 5 items and 1 factor was developed by Brehaut et al. (2003). The tool, the Turkish adaptation of which was created by Erdurcan and Kirdök (2017), includes 5 items and one factor in total. Being a 5 point Likert type scale, the tool is scored as follows: 1,00-1,80 strongly disagree; 1,81-2,60 disagree; 2,61-3,40 neither agree nor disagree; 3,41-4,20 agree; 4,21-5,00 strongly agree.

While determining the level of decision regret, the total score is obtained by adding the scale scores and multiplying by 5 . The increase from 0 to 100 in the calculated score indicates the increase in the decision regret. The total score from the scale can be stated as "it was the right decision" between 0-24, "a little regret" between 25-49, "regret the choice that was made" between 50-74 and "totally regret the choice that was made" between 75-100 (Erdurcan \& Kırdök, 2017). As the tool adapted by Erdurcan and Kirdök (2017) is 5 point-likert type $(0,1,2,3,4)$, the total score is multiplied by 5 . In the present study, the scale was used as 5 point-likert type $(1,2,3,4,5)$, the total score is multiplied by 4 in order to determine the decision regret level.

The scale was applied to different groups within the context of the Turkish adaptation version of the scale and the Cronbach Alpha reliability coefficients were found to vary across .81 and .92 . The factor loadings of the scale were calculated between .50 and .93 , and the confirmatory factor analysis revealed that the fit indices of the model were 
adequate (Erdurcan \& Kırdök, 2017). The present study has suggested that the reliability coefficient obtained from the preliminary application of the scale is .85 , while .85 after the actual application. Confirmatory Factor Analysis (CFA) has been performed through using the Mplus 7.4 packet program in order to verify the one-factor structure of the scale adapted to Turkish by Erdurcan and Kırdök (2017). Figure 1 shows the diagram model:

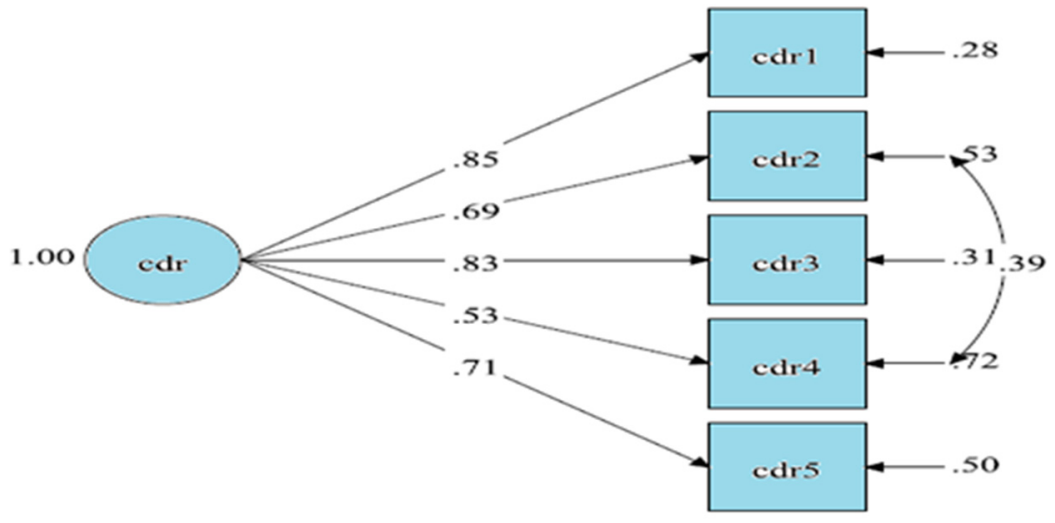

Figure 1. Career Decision Regret Scale Confirmatory Factor Analysis Model Diagram

As is seen in Figure 1, the DFA results show that the factor loadings of the scale items range between .53 and .85 , the one-factor structure of the scale is confirmed and the fit indices of the model are adequate $\left(\mathrm{x}^{2} / \mathrm{sd}=8,846 / 4=2,21\right.$, $\mathrm{CFI}=.99, \mathrm{TLI}=.98, \mathrm{RMSEA}=.058, \mathrm{SRMR}=.017)$.

\subsubsection{Job Satisfaction Scale}

The present research has deployed the Minnesota Job Satisfaction Scale-Short Form (MSQ-SF) developed by Weiss, Dawis, England and Lofquist (1967) and adapted to Turkish by İnce and Şahin (2016). All items are measured on a 5 -item response scale. Item responses are summed and averaged to create a total score, ranking as very dissatisfied 1,00-1,80; dissatisfied 1,81-2,60; can't decide if I'm satisfied or dissatisfied 2,61-3,40; satisfied 3,41-4,20; very satisfied 4,21-5,00.

Table 2 displays the total scores of job satisfaction scale and their satisfaction levels (İnce, 2014):

Table 2. Score Ranges for Satisfaction Levels of MSQ-SF

\begin{tabular}{llccc}
\hline & \multicolumn{2}{c}{ Low } & Medium & \multicolumn{2}{c}{ High } \\
& \multicolumn{2}{c}{ Dissatisfaction } & \multicolumn{2}{c}{ Satisfaction } \\
\hline Intrinsic Satisfaction & $12-15$ & $16-29$ & $30-44$ & $45-60$ \\
Extrinsic Satisfaction & $8-10$ & $11-19$ & $20-29$ & $30-40$ \\
General Satisfaction & $20-25$ & $26-49$ & $50-74$ & $75-100$ \\
\hline
\end{tabular}

Upon examining Table 2, the total scores obtained from general satisfaction and internal satisfaction and external satisfaction dimensions are evaluated as a low level of dissatisfaction, middle level of dissatisfaction, middle level of satisfaction and high level of satisfaction.

The scale consists of two sub-scales: intrinsic satisfaction and extrinsic satisfaction. All items of the scale represent general satisfaction. The scale and its factors presented high levels of reliability, with $\alpha$ values of 0.86 for the MSQ general scale, 0.82 for the intrinsic satisfaction factor and 0.78 for the extrinsic satisfaction factor. In general, the values related to item-total correlation varied between .26 and .59 and the fit indices of the model was found to be adequate and two-factor structure of the scale was confirmed.

The total scale's Cronbach's alpha reliability coefficient was re-calculated after preliminary implementation and determined to be 0.90 ; when the sub-scales were recalculated, intrinsic satisfaction and extrinsic satisfaction were determined to be $0.85,0.85$, respectively. After the actual implementation, the Cronbach's alpha reliability coefficients of the scale for the overall scale, intrinsic satisfaction and extrinsic satisfaction have been determined to be $.88, .84$ and .80 , respectively. Within the scope of this research, the CFA of the scale has been conducted. The 
diagram model obtained from the CFA result is presented in Figure 2:

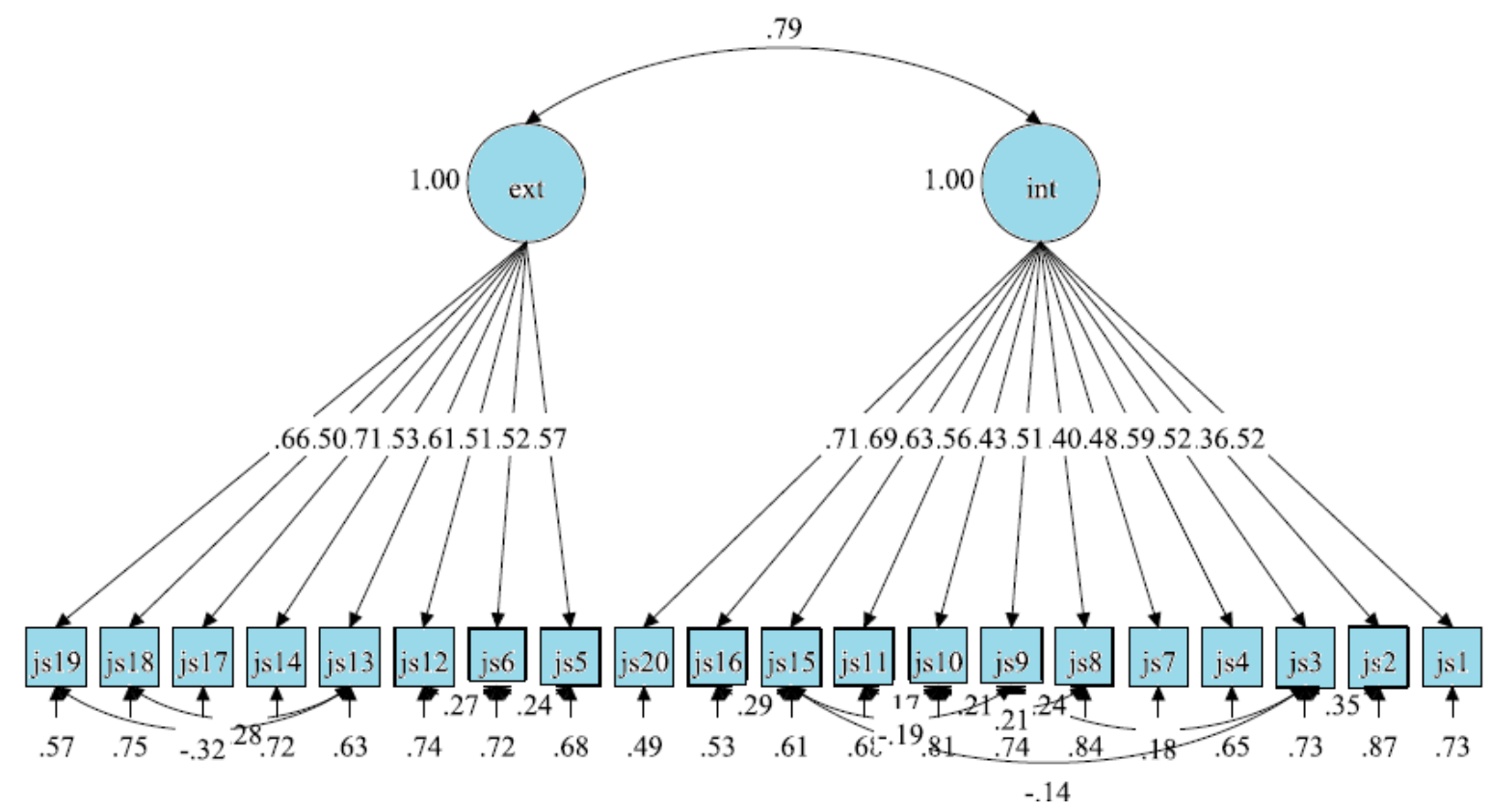

Figure 2. Job Satisfaction Scale Confirmatory Factor Analysis Model Diagram

As seen in Figure 2, the DFA results show that the two-factor structure of the scale is confirmed and the fit indices of the model are adequate $\left(\mathrm{x}^{2} / \mathrm{sd}=322,466 / 155=2,08, \mathrm{CFI}=.90, \mathrm{RMSEA}=.054, \mathrm{SRMR}=.062\right)$.

\subsubsection{Satisfaction with Life Scale}

The "Satisfaction with Life Scale" was developed by Diener, Emmons, Larsen and Griffin in 1985. The tool, the Turkish adaptation of which was created by Dağlı and Baysal (2016), includes 5 items and one factor. The Cronbach Alpha reliability coefficient of the scale was found to be .88 , and the factor loadings were calculated between .72 and .89. CFA reveals that the fit indices of the model are adequate (Dağlı \& Baysal, 2016).

The total scale's Cronbach's alpha reliability coefficient was re-calculated after preliminary implementation and determined to be 0.83 , and after the actual implementation, the Cronbach's alpha reliability coefficient of the scale was identified to be .84 for the overall scale. CFA was conducted in order to confirm the one-factor structure of the scale. The diagram model obtained from the CFA result is presented in Figure 3:

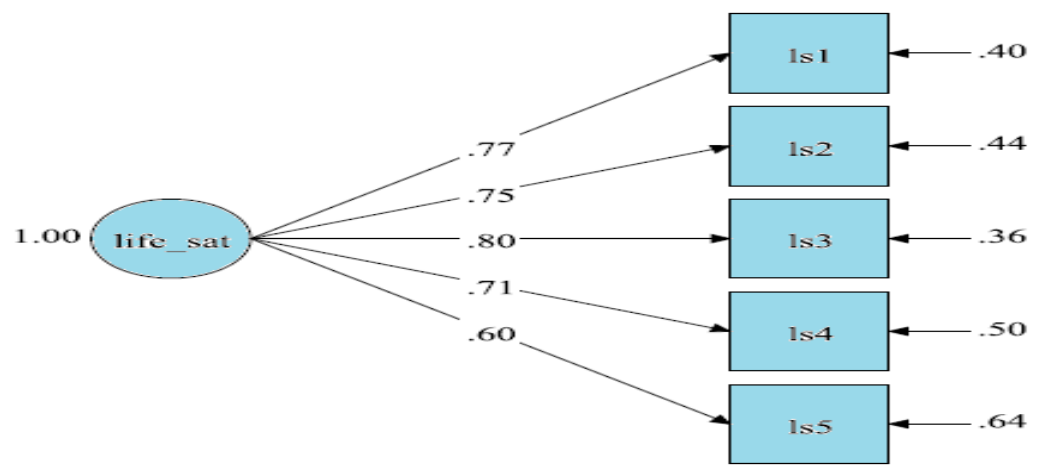

Figure 3. Satisfaction with Life Scale Confirmatory Factor Analysis Model Diagram

As seen in Figure 3, the CFA results show that the factor loadings of the items varied between .60 and .80 and that one-factor structure of the scale is confirmed and the fit indices of the model are adequate $\left(\mathrm{x}^{2} / \mathrm{sd}=6,276 / 5=1,25\right.$, $\mathrm{CFI}=.99, \mathrm{TLI}=.99, \mathrm{RMSEA}=.026, \mathrm{SRMR}=.014)$.

Being a 5 point-likert type scale, the scores obtained from the scale were ranked as; 1,00-1,80 strongly disagree; 
1,81-2,60 slightly agree; 2,61-3,40 neither agree nor disagree; 3,41-4,20 agree; 4,21-5,00 strongly agree.

\subsection{Data Collection and Analysis}

Necessary permissions have been obtained from Dağlı and Baysal (2016), Erdurcan and Kırdök (2017) and İnce and Şahin (2016) via e-mail in order to use the data collection tools in the research. Official permission has been obtained from Kahramanmaraş Provincial Directorate of National Education with a view to applying the data collection tools, explanations have been made to the schools regarding the application and after the distribution of the measurement tools to the participants, the scale forms have been asked to be responded anonymously.

The research data have been analyzed through SPSS for Windows 21.0 and Mplus 7.4 package programs. The Skewness values are calculated in order to demonstrate whether the data showed normal distribution (Büyüköztürk, 2017), and the skewness values have been found to be $-.484 ;-.108 ;-.504 ;-.147 ;-.774$, respectively for the Career Decision Regret Scale, Life Satisfaction Scale, Job Satisfaction Scale and its subscales-Intrinsic Satisfaction and Extrinsic Satisfaction. All values have been determined to be between +1 and -1 and the data demonstrated normal distribution. Arithmetic mean and standard deviation values, Independent groups t-test in determining the relationship between variables and one-way ANOVA test have been used during data analysis. Pearson Correlation analysis has been performed to determine the relationship between the variables. Linear regression analysis was also applied to determine the degree at which career decision regret predicts job satisfaction and life satisfaction.

\section{Results}

This section presents findings related to the research questions.

\subsection{Findings Related to Participants' Career Decision Regret, Job Satisfaction and Satisfaction with Life Levels}

Table 3 depicts average, standard deviation and total score values related to the participants' career decision regret, job satisfaction and satisfaction with life levels.

Table 3. Average, Standard Deviation and Total Score Values Related to the Participants' Career Decision Regret, Job Satisfaction and Satisfaction with Life Levels

\begin{tabular}{lllllllllll}
\hline & & \multicolumn{3}{c}{ Teachers } & \multicolumn{5}{c}{ School Administrators } \\
\cline { 3 - 10 } Scales & Dimensions & $\mathbf{N}$ & $\overline{\boldsymbol{X}}$ & SD & $\begin{array}{c}\text { Total } \\
\text { Score }\end{array}$ & $\mathbf{N}$ & $\overline{\boldsymbol{X}}$ & SD & $\begin{array}{c}\text { Total } \\
\text { Score }\end{array}$ \\
\hline Career Decision Regret & Career Decision Regret & 316 & 3,73 & .94 & 11,30 & 50 & 3,70 & .85 & 11,46 \\
& General Satisfaction & 316 & 3,34 & .58 & 66,99 & 50 & 3,43 & .55 & 68,71 \\
Job Satisfaction & Intrinsic Motivation & 316 & 3,68 & .61 & 44,19 & 50 & 3,72 & .58 & 44,65 \\
& Extrinsic Motivation & 316 & 2,85 & .73 & 22,80 & 50 & 3,00 & .68 & 24,06 \\
Satisfaction with Life & Satisfaction with Life & 316 & 3,06 & .80 & 15,33 & 50 & 3,28 & .86 & 16,44 \\
\hline
\end{tabular}

\subsubsection{Career Decision Regret Level}

Table 3 has suggested that the arithmetic mean of the teachers' views on career decision regret is $\bar{X}=3,73$ (total score $=11,30)$ and $X=3,70$ (total score $=11.46)$. Considering that the total score of the teachers which is 11,30 (Total Score $=11,30 \times 4=45,20$ ), it has been found that teachers' career decision regret has been found to be at "a little" level. Taking school administrators' total score 11,46 into account (Total Score=11,46x4=45,84), their career decision regret has been determined to be at "a little" level.

\subsubsection{Job Satisfaction Level}

Upon examining Table 3, the arithmetic mean of job satisfaction levels of teachers are 3,34;3,68 and 2,85 for general satisfaction, intrinsic satisfaction and extrinsic satisfaction subscales, respectively. Given the scores between "2.61-3.40" are at the "neither agree nor disagree" level and those between "3,41-4,20" are at the "agree" level, teachers have been identified to "Agree" in terms of general satisfaction and intrinsic satisfaction, while they are at the level of "neither agree nor disagree" in terms of extrinsic satisfaction, meaning that they are undecided whether they are satisfied or not. When the scale has been evaluated in terms of the total score (taking into account the intervals in Table 2), teachers have been determined to hold a general satisfaction total score of 66.99, which is medium level general satisfaction; the total intrinsic satisfaction score is 44.19 , meaning that they have experienced a medium level of intrinsic satisfaction; and the extrinsic satisfaction total score is 22,80 , which means that they have 
experienced a medium level of extrinsic satisfaction.

Table 3 displays that the arithmetic mean of the job satisfaction levels of the school administrators is $3.43 ; 3,72$ and 3,00 for the general satisfaction, intrinsic satisfaction and extrinsic satisfaction subscales. Considering the scores between "2.61-3.40" are at the "neither agree nor disagree" level and those between "3,41-4,20" are at the "agree" level, school administrators have been determined to "Agree" in terms of general satisfaction and intrinsic satisfaction, while they are at the level of "neither agree nor disagree" in terms of extrinsic satisfaction, meaning that they are undecided whether they are satisfied or not. When the scale has been evaluated in terms of the total score (taking into account the intervals in Table 2), school administrators have been noted to have a general satisfaction total score of 68.71 , which is medium level general satisfaction; the total intrinsic satisfaction score is 44.65 , meaning that they have experienced a medium level of intrinsic satisfaction; and the extrinsic satisfaction total score is 24.06 , which means that they have experienced a medium level of extrinsic satisfaction.

\subsubsection{Life Satisfaction Level}

Table 3 has also revealed that the arithmetic mean of life satisfaction levels of teachers and school administrators is 3,06 and 3,25. Considering the scores between "2.61-3.40" are at the "neither agree nor disagree" level, teachers and school administrators have been determined to be indecisive in terms of whether they are satisfied with their lives. This may also be explained by the fact that teachers and school administrators are unconfident in being satisfied with their lives.

3.2 Examination of the Participants' Views Regarding Career Decision Regret in terms of Several Variables (Gender, Marital Status, Graduation Status, Institution Type, Seniority, Job Type)

Table 4 presents "Independent Samples t-test" and "One-way variance of analysis (ANOVA) results conducted to determine whether participants' career decision regret levels vary across their demographic characteristics.

Table 4. Analyzing Participants' Career Decision Regret in terms of Several Demographic Characteristics

\begin{tabular}{|c|c|c|c|c|c|c|c|c|c|c|c|c|}
\hline \multirow[t]{2}{*}{ Dimensions } & \multicolumn{2}{|c|}{ Gender } & \multicolumn{2}{|c|}{$\begin{array}{c}\text { Marital } \\
\text { Status }\end{array}$} & \multicolumn{2}{|c|}{$\begin{array}{c}\text { Graduation } \\
\text { Status }\end{array}$} & \multicolumn{2}{|c|}{$\begin{array}{c}\text { Institution } \\
\text { Type }\end{array}$} & \multicolumn{2}{|c|}{ Seniority } & \multicolumn{2}{|c|}{ Job Type } \\
\hline & $\mathrm{t}$ & $\mathrm{p}$ & $\mathrm{T}$ & $\mathrm{p}$ & $\mathrm{t}$ & $\mathrm{p}$ & $\mathrm{F}$ & $\mathrm{p}$ & $\mathrm{F}$ & $\mathrm{p}$ & $\mathrm{t}$ & $\mathrm{P}$ \\
\hline Career Decision Regret & -.03 & .97 & .42 & .67 & .02 & .98 & .32 & .80 & .63 & .63 & .05 & .81 \\
\hline
\end{tabular}

Upon analyzing Table 4, no significant difference has been noted across participants' views on career decision regret in terms of their gender, marital status, graduation status, institution type, seniority, job type.

3.3 Examination of the Participants' Views Regarding Job Satisfaction in terms of Several Variables (Gender, Marital Status, Graduation Status, Institution Type, Seniority, Job Type)

Table 5 depicts "Independent Samples t-test" and "One-way variance of analysis (ANOVA) results conducted to identify whether participants' job satisfaction levels differ across their demographic characteristics.

Table 5. Analyzing Participants' Job Satisfaction in Terms of Several Demographic Characteristics

\begin{tabular}{|c|c|c|c|c|c|c|c|c|c|c|c|c|}
\hline \multirow[t]{2}{*}{ Dimensions } & \multicolumn{2}{|c|}{ Gender } & \multicolumn{2}{|c|}{$\begin{array}{l}\text { Marital } \\
\text { Status }\end{array}$} & \multicolumn{2}{|c|}{$\begin{array}{c}\text { Graduation } \\
\text { Status }\end{array}$} & \multicolumn{2}{|c|}{$\begin{array}{c}\text { Institution } \\
\text { Type }\end{array}$} & \multicolumn{2}{|c|}{ Seniority } & \multicolumn{2}{|c|}{ Job Type } \\
\hline & $\mathrm{t}$ & $\mathrm{p}$ & $\mathrm{t}$ & $\mathrm{p}$ & $t$ & $\mathrm{P}$ & $\mathrm{F}$ & $\mathrm{p}$ & $\mathrm{F}$ & $\mathrm{p}$ & $\mathrm{T}$ & $\mathrm{p}$ \\
\hline General Satisfaction & .49 & .62 & $.2,06$ & $.04^{*}$ & -.78 & .43 & 1,02 & .38 & .91 & .54 & -.95 & .33 \\
\hline Intrinsic Satisfaction & -.27 & .78 & 1,07 & .28 & -.21 & .83 & .53 & .65 & 1,39 & .23 & -.40 & .68 \\
\hline Extrinsic Satisfaction & 1,34 & .18 & 2,80 & $.00^{*}$ & $-1,31$ & .18 & 1,46 & .22 & .71 & .58 & $-1,41$ & .15 \\
\hline
\end{tabular}

A closer look at participants' views regarding job satisfaction (general satisfaction, intrinsic satisfaction and extrinsic satisfaction) indicates no significant difference in terms of their gender, graduation status, institution type, seniority, job type ( $\mathrm{p}>.05)$; whereas a statistically significant difference has been determined between participants' job satisfaction levels depending on their marital status. The difference has been found to be in favor of participants who are single in terms of general satisfaction $\left[\overline{\mathrm{X}}_{\text {single }} 3,53, \overline{\mathrm{X}}_{\text {married }} 3,33, t(956)=2,06, p<.05\right]$ and extrinsic satisfaction subscale $\left[\overline{\mathrm{X}}_{\text {single }}=3,15 ; \overline{\mathrm{X}}_{\text {married }}=2,83, t(126)=2,80, p<.05\right]$. 
3.4 Examination of the Participants' Views Regarding Life Satisfaction in terms of Several Variables (Gender, Marital Status, Graduation Status, Institution Type, Seniority, Job Type)

Table 6 suggests "Independent Samples t-test" and "One-way variance of analysis (ANOVA) results conducted to determine whether participants' life satisfaction levels vary across their demographic characteristics.

Table 6. Analyzing Participants' Life Satisfaction in terms of Several Demographic Characteristics

\begin{tabular}{|c|c|c|c|c|c|c|c|c|c|c|c|c|}
\hline Dimensions & \multicolumn{2}{|c|}{ Gender } & \multicolumn{2}{|c|}{$\begin{array}{c}\text { Marital } \\
\text { Status } \\
\end{array}$} & \multicolumn{2}{|c|}{$\begin{array}{c}\text { Graduation } \\
\text { Status } \\
\end{array}$} & \multicolumn{2}{|c|}{$\begin{array}{c}\text { Institution } \\
\text { Type }\end{array}$} & \multicolumn{2}{|c|}{ Seniority } & \multicolumn{2}{|c|}{ Job Type } \\
\hline Satisfaction with Life & $\begin{array}{c}\mathrm{t} \\
1,04 \\
\end{array}$ & $\begin{array}{c}\mathrm{p} \\
.29 \\
\end{array}$ & $\begin{array}{c}\mathrm{T} \\
-.05 \\
\end{array}$ & $\begin{array}{c}\mathrm{p} \\
.95 \\
\end{array}$ & $\begin{array}{c}\mathrm{T} \\
-.73 \\
\end{array}$ & $\begin{array}{l}\mathrm{p} \\
.46 \\
\end{array}$ & $\begin{array}{l}\mathrm{F} \\
.95 \\
\end{array}$ & $\begin{array}{l}\mathrm{p} \\
.41 \\
\end{array}$ & $\begin{array}{c}\mathrm{F} \\
1,13 \\
\end{array}$ & $\begin{array}{c}\mathrm{p} \\
.33 \\
\end{array}$ & $\begin{array}{c}\mathrm{t} \\
-1,77 \\
\end{array}$ & $\begin{array}{c}\mathrm{p} \\
.07 \\
\end{array}$ \\
\hline
\end{tabular}

As seen in Table 6, no significant difference has been identified across the participants' views on life satisfaction in terms of their gender, marital status, graduation status, institution type, seniority, job type ( $\mathrm{p}>.05)$.

\subsection{Findings Related to the Relation between Career Decision Regret, Job Satisfaction and Life Satisfaction}

Pearson Correlation Coefficient has been calculated so as to identify the relationship between career decision regret, job satisfaction (general satisfaction, intrinsic satisfaction, extrinsic satisfaction) and life satisfaction.

The diagram of the model showing the relationship between the variables is presented in Figure 4:

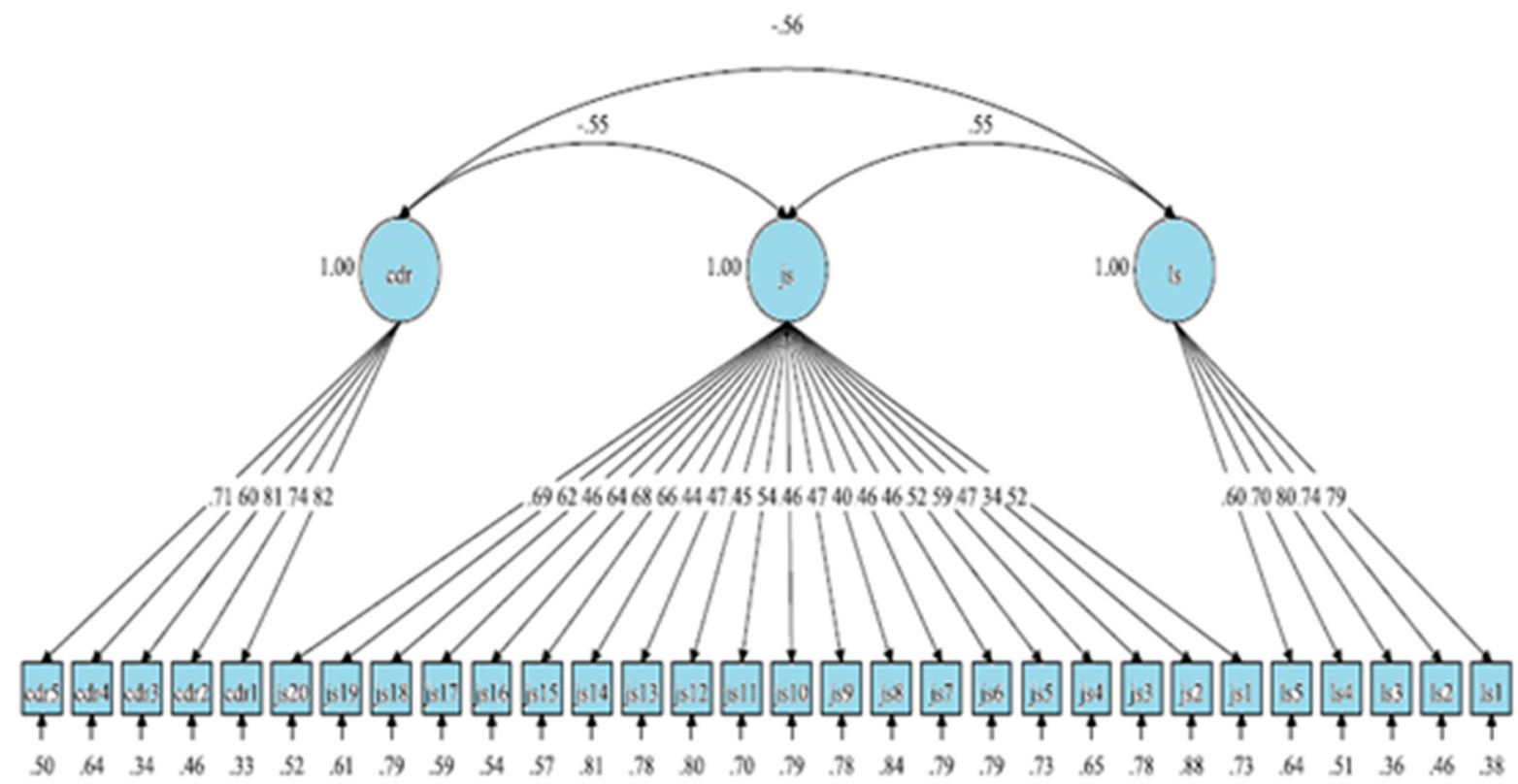

Figure 4. Model Diagram Related to the Relationship between Career Decision Regret, Job Satisfaction and Life Satisfaction

Figure 4 shows that there is a negative and medium level correlation between career decision regret and life satisfaction $(r=-.55, p<.05)$. In other words, the level of life satisfaction may decrease as the career decision regret increases, while the level of life satisfaction may increase as the level of career decision regret decreases.

Similarly, Figure 4 suggests a negative and medium level correlation between career decision regret and job satisfaction $(r=-.56, p<.05)$. In other words, the level of job satisfaction may decrease as the career decision regret increases, while the level of job satisfaction may increase as the level of career decision regret decreases.

A positive and medium level correlation has been found between job satisfaction and life satisfaction $(r=.55, p<.05)$. Namely, the level of job satisfaction may increase as life satisfaction increases, while the level of job satisfaction may increase as the level of job satisfaction increases. 


\subsection{Findings Related to How Career Decision Regret Predicts Job Satisfaction and Life Satisfaction}

Two different regression analyzes were conducted in order to demonstrate whether the career decision regret is a significant predictor of job satisfaction and life satisfaction, and regression models were revealed. The first model shows as to how career decision regret predicts job satisfaction, while the other depicts how career decision regret predicts life satisfaction. The regression analysis results are shown in Table 7 and 8.

Model 1: Findings Related to How Career Decision Regret Predicts Job Satisfaction

Table 7. Job Satisfaction Prediction Status of Career Decision Regret

\begin{tabular}{lccccc}
\hline Variable & B & Sh & B & t & P \\
\hline Stable & 2.192 & .110 & & 19,999 & .000 \\
Career Decision Regret & .313 & .028 & .500 & 11,001 & .000 \\
$\mathrm{R}=0.500 \mathrm{R}^{2}=0.250 \mathrm{~F}=121,18 \mathrm{p}=.000$ & & & & &
\end{tabular}

When Table 7 has been examined, the linear regression analysis reveals that career decision regret is a significant predictor of job satisfaction and $25 \%$ of the total variance of job satisfaction level of teachers is explained by career decision regret. According to the regression analysis, the regression equation (mathematical model) related to the prediction of career decision regret to the job satisfaction is as follows:

Job Satisfaction $=2.192+(.313 \times$ Career Decision Regret $)$.

Model 2: Findings Related to How Career Decision Regret Predicts Life Satisfaction

Table 8. Findings Related to How Career Decision Regret Predicts Life Satisfaction

\begin{tabular}{lccccc}
\hline Variable & B & Sh & B & t & P \\
\hline Stable & 1.526 & .156 & & 9,762 & .000 \\
Career Decision Regret & .421 & .041 & .478 & 10,364 & .000 \\
\hline
\end{tabular}

$\mathrm{R}=0.478 \mathrm{R}^{2}=0.229 \mathrm{~F}=107,422 \mathrm{p}=.000$

Table 8 demonstrates the linear regression analysis results, showing that career decision regret is a significant predictor of life satisfaction and $22 \%$ of the total variance of life satisfaction level of teachers is explained by career decision regret. Regression analysis revealed that the regression equation (mathematical model) related to the prediction of career decision regret to the life satisfaction is as follows:

Life Satisfaction $=1.526+(.421 \times$ Career Decision Regret $)$.

\section{Discussion}

This section holds research results, discussion, and recommendations for practitioners and researchers.

\subsection{Teachers' and School Administrators" Career Decision Regret, Job satisfaction and Life Satisfaction Levels}

Research results have revealed that teachers and school administrators" career decision regret is at the "little" level. When the relevant literature has been examined, no research has been conducted on teachers or school administrators analyzing the career decision regret and the level of career decision regret. However, in a study conducted by Hamamcı and Çoban (2007), students' career decision regret level has been found to be low. Bacanlı (2013) has concluded that female students have significantly higher mean scores of career decision difficulties compared to males, students who decide on their career and who possess low perceptions towards their academic achievement have significantly higher level of career decision difficulties than those who do not. Öztemel (2012) has noted that career selection indecisions of the students who continue to vocational and technical high schools have been determined to be higher than the academic high school students (general high school students).

The individual's career choice decision is negatively or positively influenced by many factors (Çakır, 2004). The negative/wrong or positive/correct factors that are effective in the career choice will determine the existence and level of regret that the individual will experience while choosing the profession. The fact that the factors affecting the choice of profession are wide and diverse will naturally bring about the different levels of career decision regret. Each complex entity, called as a human being, may be affected differently, even from the same situation, which is considered as a predictor of different levels of regret that will emerge in individuals. 
As a result of the research; teachers and school administrators have been identified to "Agree" in terms of general satisfaction and intrinsic satisfaction, while they are at the level of "neither agree nor disagree" in terms of extrinsic satisfaction, meaning that they are undecided whether they are satisfied or not. Considering the total scores, it has been found that teachers and school administrators have a medium level of general satisfaction, intrinsic satisfaction and extrinsic satisfaction. Similar results have emerged in the studies conducted by Altınkurt \& Y1lmaz, 2014; Ayan, Kocacık \& Karakuş, 2009; Çakmak \& Arabacı, 2017; Çolak, Altınkurt, \& Yılmaz, 2017; Demirtaş \& Nacar, 2018; Gergin, 2006; İnce \& Şahin, 2016; Yılmaz, 2012. However, in the studies conducted by Aşlamac1, 2017; Kumaş \& Deniz, 2010; Taşdan \& Tiryaki, 2008, teachers have been found to possess high job satisfaction levels. In another study conducted by Akın and Koçak (2007), findings regarding job satisfaction level of teachers indicated that $19.7 \%$ of teachers have "very high", $27.1 \%$ have "high", $29.4 \%$ "average", $17 \%$ have "low" and $6.5 \%$ have "very low" job satisfaction. Ordu (2016) has concluded that teachers respond as "satisfied" level for the items about intrinsic and general satisfaction; "nor agree or disagree" for the items about extrinsic satisfaction. In addition, Çifçili (2008) has indicated that teachers with a high level of efficacy have a low level of job satisfaction. There are similar studies supporting the result of the present study "teachers experience medium level job satisfaction", still there are also researches indicating high and low-level job satisfaction. This may be explained by various different reasons directly affecting teachers and school administrators, such as their socio-demographic characteristics the climate and culture of the institutions they work, the management and leadership styles displayed in the organizations, and the social, personal and academic achievement characteristics of the students.

Research results have also revealed that teachers and school administrators' life satisfaction is at the "neither agree nor disagree" level. Accordingly, they have been determined to be indecisive in terms of whether they are satisfied with their lives. The related literature includes many researches which examine the life satisfaction of the teachers. The majority of these studies have explored the relationship between participants' life satisfaction level and several demographic characteristics (Avşaroğlu, Deniz, \& Kahraman, 2005; Kırcı-Çevik \& Korkmaz, 2014; Recepoğlu, 2013; Yilmaz \& Aslan, 2013). The research conducted by Yilmaz and Altınok (2009) has suggested that school administrators have medium level life satisfaction; besides, Demirel (2014) has determined that the life satisfaction of the teachers is above the middle level. In another study conducted with different sample group, it has been found that $20 \%$ of the students have low satisfaction level, $50 \%$ have an average level and $20 \%$ have a high level of life satisfaction (Gilman \& Huebner, 2006).

Various studies have shown that the life satisfaction of teachers and administrators is at different levels. This may be considered as an expected result since the varying factors affecting the life satisfaction of the individuals may be regarded as a possible cause of the difference in life satisfaction levels (Keser, 2005; Dockery, 2004, Khakoo, 2004; Cited in Özdevecioğlu \& Aktaş, 2007; Özdevecioğlu \& Aktaş, 2007).

\subsection{The Participants' Views Regarding Career Decision Regret, Job Satisfaction and Life Satisfaction in terms of} Several Demographic Variables

Research results have revealed that there is no significant difference across participants' views on career decision regret in terms of their gender, marital status, graduation status, institution type, seniority, job type. There exists no such a study that examines whether career decision regret varies across several demographic characteristics. Upon examining other studies related to career choice decision; as a result of the study on career decision making difficulty, female students have significantly higher mean scores of career decision difficulties compared to males, students who decide on their career and who possess low perceptions towards their academic achievement have significantly higher level of career decision difficulties than those who do not (Bacanl1, 2012); besides, career selection indecisions of the students who continue to vocational and technical high schools have been determined to be higher than the academic high school students (general high school students) (Öztemel, 2012).

There may be various underlying reasons for the employees' career decision regret. A great number of individual, organizational and environmental problems can be listed as the reasons for career decision regret: An employee does not intentionally choose his/her job, positive attitude towards profession changes in time due to the situations that will adversely affect an employee's attitudes towards profession, disappointment about the profession, experiencing individual problems (economic, family, health, etc.). In this respect, the result of this research "the participants' career decision regret does not significantly differ in terms of demographic characteristics" may vary across the results of research conducted with different samples.

A closer look at participants' views regarding job satisfaction (general satisfaction, intrinsic satisfaction and extrinsic satisfaction) indicates no significant difference in terms of their gender, graduation status, institution type, seniority, job type; whereas a statistically significant difference has been determined between participants' job satisfaction 
levels depending on their marital status. The difference has been found to be in favour of participants who are single in terms of general satisfaction and extrinsic satisfaction subscale. In his study, Telef (2011) has noted that teachers' job satisfaction scores do not significantly differ across their gender, age, educational status, working status, type of school, seniority and lifespan at school. Özben and Argun (2005) have stated that teachers' job satisfaction levels significantly vary across gender, age and seniority; however, no significant difference has been identified in terms of their marital status and income level. Ayan, Kocacık, and Karakuş (2009) have found that job satisfaction level of teachers who have less than one year experience, who express their opportunity for being promoted and who are satisfied with the running of the institution is significantly higher than those who do not. Gençtürk and Memiş (2010) have found a significant difference in terms of gender and graduation school while no significant difference has been determined in terms of seniority and branch; Kumaş and Deniz (2010) have concluded that job satisfaction based on internal and external factors of female teachers is higher compared to males, and younger teachers' job satisfaction level based on external factors (20-25) is higher than that of older teachers. In another study (İnce and Şahin, 2016), it has been found a significant difference in favour of teachers working in independent class; Akman, Kelecioğlu, and Bilge (2006) and Ma and MacMillan (1999) have determined significant differences in terms of gender and seniority. Besides, in their study, Taşdan and Tiryaki (2008) have found that the level of job satisfaction does not significantly differ depending on gender, seniority and school type. The results of the research conducted by Koruklu, Feyzioğlu, Özenoğlu-Kiremit, and Aladağ (2013) have suggested that job satisfaction levels of the teachers significantly vary across their age, school type, physical conditions of the school, relationship with the colleagues, the renewed secondary school curriculum, transition examination system to universities, and participation levels in in-service trainings. The results of the study carried out by Çifçili (2008) have demonstrated that there is a statistically significant difference depending on the executed program (OSS or OKS preparation courses) and following periodical. One such study conducted by Şahin and Dursun (2009) indicated that pre-school teachers' job satisfaction levels do not differ across their age, marital status, seniority and monthly income; besides, job satisfaction levels of teachers who are appreciated by their administrators and who think that the financial potential of the school is adequate are higher compared to those who are not appreciated by their administrators and who emphasize the lack of financial potential in the school. This research result is in line with some different research results and also differs from some research results. This difference may be due to the socio-demographic characteristics of the participants, the characteristics of the working environment of the organization, the socio-cultural environment characteristics of the participants as well as the diversity of the institutions (private school-state school).

Research results have put forward that participants' views on life satisfaction do not significantly differ in terms of their gender, marital status, graduation status, institution type, seniority and job type. Upon examining the results of different researches; Recepoğlu and Ülker-Tümlü (2015) have found that the level of academic staff' life satisfaction does not significantly vary across their gender, age, marital status, degree, year of service and year of service at the university. Avşaroğlu, Deniz, and Kahraman (2005) have declared that life satisfaction levels of teachers do not significantly differ in terms of their gender, age and year of service; Y1lmaz and Aslan (2013) have suggested that the life satisfaction of teachers does not significantly differ across their gender, but they have found a significant difference in favour of the married teachers. Besides, Yilmaz, and Altınok (2009) have also asserted that school administrators' life satisfaction scores significantly differ in terms of their seniority and income levels, and that there is no significant difference in terms of the educational status. There are numerous studies showing that the life satisfaction of employees varies in terms of their demographic characteristics. Individuals' life satisfaction is influenced by many different situations and variables (Keser, 2005; Khakoo, 2004; Dockery, 2004; Özdevecioğlu \& Aktaş, 2007; Özdevecioğlu \& Aktaş, 2007). The difference in the situation and variables affecting the life satisfaction of the individuals may be regarded as a reason for the difference in their life satisfaction levels.

\subsection{The Relationship between Career Decision Regret, Job Satisfaction and Life Satisfaction}

One of the research results has suggested a negative and medium level correlation between career decision regret and life satisfaction. In other words, the level of life satisfaction may decrease as the career decision regret increases, while the level of life satisfaction may increase as the level of career decision regret decreases. In addition, there has been found a negative and medium level correlation between career decision regret and job satisfaction. In other words, the level of job satisfaction may decrease as the career decision regret increases, while the level of job satisfaction may increase as the level of career decision regret decreases. A positive and medium level correlation has been determined between job satisfaction and life satisfaction. Namely, the level of job satisfaction may increase as life satisfaction increases, while the level of job satisfaction may increase as the level of job satisfaction increases.

When the relevant literature has been analyzed, there exists no study that examines the relationship between the career decision regret and a different variable. However, there has been found various studies directly exploring the 
relationship between job satisfaction and life satisfaction. These studies have clarified a significant and positive relationship (Avşaroğlu, Deniz, \& Kahraman, 2005); a casual relationship (Kırcı-Çevik \& Korkmaz, 2014); a significant low relationship (Demirel, 2014); a moderate level relationship (Dikmen, 1995); positive and medium level relationship (Recepoğlu \& Ülker-Tümlü, 2015; Telef, 2011) between teachers' life satisfaction and job satisfaction. Although the research results suggest different levels of relationship, there is a relation between job satisfaction and life satisfaction.

Considering the studies conducted to determine the relation between job satisfaction and different variables; there is a medium level relationship between job satisfaction and level of organizational commitment (Yaramış \& Çınkır, 2014); a significant and medium level correlation between job satisfaction and professional development (Hamamc1, Oskargil-Göktepe, \& İnanç, 2005); the effect of motivation tools on job satisfaction (Ağırbaş, Çelik, \& Büyükkayıkçı, 2005); a relationship between burnout and job satisfaction (Özben \& Argun, 2005); a relationship between job satisfaction and motivation (Toker, 2006).

What is more, there are also research results referring to the relationship between life satisfaction and different variables. Özdevecioğlu and Aktaş (2007) have noted a positive relationship between life satisfaction and career loyalty, professional loyalty, organizational loyalty; Recepoğlu (2013) has identified a significant, positive and medium level relationship between life satisfaction and attitude towards the teaching profession; Y1lmaz and Altınok (2009) have offered that there exists a negative relationship between school administrators' loneliness and life satisfaction levels; Y1lmaz and Aslan (2013) have also demonstrated a significant and negative correlation between life satisfaction scores of teachers and their emotional deprivation and social friendship scores; Y1lmaz and Sünbül (2009) have considered that there is a significant positive relationship between teachers' life satisfaction and school organizational trust, sensitivity to employees, managerial trust, communication environment and openness to innovation. As a result, it may be wise to mention that the result of this research that "there is a positive relationship between job satisfaction and life satisfaction" is in line with those of other researches.

\subsection{Career Decision Regret as a Predictor of Job Satisfaction and Life Satisfaction}

The analysis results have revealed that career decision regret is a significant predictor of teachers' school administrators' job satisfaction and life satisfaction levels. Accordingly, $25 \%$ of the total variance of job satisfaction level of teachers is explained by career decision regret, while $22 \%$ of the total variance of life satisfaction level of teachers by career decision regret. Along with this result of the research; there are some studies showing that job satisfaction is a significant predictor of life satisfaction (Lent, Nota, Soresi, \& Ginevra, 2011; Recepoğlu \& Ülker-Tümlü, 2015); nevertheless, no study has been found related to how career decision regret predicts life satisfaction and job satisfaction. However, it is also widely known that job decisions made by the individuals affect their job satisfaction and life satisfaction. If the career choice is not made in accordance with the life preferences of the individual, the possible consequences of this inconvenience (Öztemel, 2012) will directly affect the life of the individual in the following periods, and the individual will be unsuccessful and inefficient when an inappropriate job is chosen (Sarıkaya \& Khorshid, 2009). Thus, it can be argued that career decision regret affects the individual's job satisfaction and life satisfaction.

\section{Recommendations}

\subsection{Recommendations for Practitioners}

1. Research results have revealed that teachers and school administrators' career decision regret is at "a little" level. It is a necessity in terms of the quality of education for those who perform the tasks of teaching and school administration to love their profession, to devote themselves to their profession and to have no regret about their profession. In this respect, the inventories may be developed and applied by county/province national education directorates and the Ministry of National Education in order to unveil the reasons of career decision regret experienced by teachers and school administrators (even if at a low level). Cooperation may be ensured between the Ministry of National Education and the Council of Higher Education in the centre and the provincial/district national education directorates and education faculties.

2. One of the research results has shown that life satisfaction levels of teachers and school administrators are at "neither agree nor disagree" level. Social activities may be planned by the district / provincial national education directorates and the Ministry of National Education's human resources departments with the aim of increasing the life satisfaction levels of the teachers and school administrators. Social, sportive and artistic activities may be realized in order to contribute to the happiness of the employees in the business environment. 
3. As a result of the research, a negative and medium level relation has been found between career decision regret and life satisfaction, and between career decision regret and job satisfaction; whereas there has been identified a positive and medium level relationship between job satisfaction and life satisfaction. Individuals' career decision regret may affect their life satisfaction and job satisfaction negatively. In this respect;

- Teachers and guidance services, especially in secondary education institutions, can be much more sensitive while addressing students about the teaching profession. Training activities may be organized for teachers, guidance teachers and school administrators in order to increase the competency of how to make scientific career guidance. In this regard, parents' awareness on this issue can be increased.

- Teachers, school administrators, teacher training institutions and people can continuously consider that the selection and promotion of the individuals who will prefer the teaching profession are paramount in terms of the education system and the future of the society. Thus, the process of selecting teachers, raising and supporting them in their profession may be much more qualified.

- Scales may be administered to the students (secondary-high school) at certain times so as to determine their professional orientations and interests, thus leading them to the appropriate departments/fields.

- Student admission may be preferred by applying the developed/ being developed tests to determine their attitudes and professional interests in addition to central examinations during student acceptance to the education faculties.

4. Another result of the research has indicated that career decision regret is a significant predictor of job satisfaction and life satisfaction of teachers and school administrators. In this respect, the effect of employees' decisions towards their job choice on their life satisfaction and job satisfaction should be taken into consideration by the teachers, school administrators, education administrators and students who would prefer a profession.

\subsection{Recommendations for Researchers}

1. Research results have suggested no significant difference between participants' views on career decision regret, job satisfaction and life satisfaction in terms of gender, graduation status, institution type, seniority and job type, yet a significant difference has been observed in terms of their marital status. The difference has been determined to be in favour of single participants in general satisfaction and extrinsic satisfaction dimensions. Upon analyzing the relevant literature, numerous studies have been conducted that are similar and different from the results of this research. Hence, a meta-analysis study may be conducted in which different research results can be evaluated together.

2. This research has explored the relationship between career decision regret with life satisfaction and job satisfaction. Different studies can examine the relation between career decision regret and different variables such as burnout, professional attitude and subjective well-being.

3. Research results have clarified that teachers and school administrators experienced "a little" level of professional regret. The reasons for this result can be analyzed in depth with the interview method which is one of the qualitative research methods and with the involvement of the teachers and administrators in the research sample.

4. Quantitative researches can be conducted in order to examine the levels of career decision regret of teachers and school administrators working in different provinces and regions.

\section{Highlights}

The research results have revealed that teachers and school administrators' career decision regret is at the "little" level. There has been found no significant difference across participants' views on career decision regret in terms of their gender, marital status, graduation status, institution type, seniority, job type. There is a negative and medium level correlation between career decision regret and life satisfaction. Career decision regret has been identified to be a significant predictor of teachers' school administrators' job satisfaction and life satisfaction levels. Accordingly, $25 \%$ of the total variance of job satisfaction level of teachers is explained by career decision regret, while $22 \%$ of the total variance of life satisfaction level of teachers by career decision regret.

\section{References}

Ağırbaş, İ., Çelik, Y., \& Büyükkayıkçı, H. (2005). Motivasyon araçları ve iş tatmini: Sosyal sigortalar kurumu başkanlığı başhekim yardımcıları üzerinde bir araştırma. Hacettepe Sağllk İdaresi Dergisi, 8(3), 326-350.

Akın, U., \& Koçak, R. (2007). Öğretmenlerin sınıf yönetimi becerileri ile iş doyumları arasındaki ilişki. Kuram ve Uygulamada Ĕ̈itim Yönetimi, 51, 353-370. 
Akman, Y., Kelecioğlu, H., \& Bilge, F. (2006). Öğretim elemanlarının iş doyumlarını etkileyen faktörlere ilişkin görüşleri. Hacettepe Üniversitesi Eğitim Fakültesi Dergisi, 30, 11-20.

Altınkurt, Y., \& Kürşat, Y. (2014). Öğretmenlerin mesleki profesyonelliği ile iş doyumları arasındaki ilişki. Sakarya University Journal of Education, 4(2), 57-71. https://doi.org/10.19126/suje.46033

Aşlamacı, İ. (2017). İmam-hatip liselerinde görev yapan öğretmenlerin mesleki doyum düzeylerinin çeşitli değişkenler açısından incelenmesi. Hitit Üniversitesi İlahiyat Fakültesi Dergisi, 16(31), 175-201.

Ayan, S., Kocacık, F., \& Karakuş, H. (2009). Lise öğretmenlerinin iş doyumu düzeyi ile bunu etkileyen bireysel ve kurumsal etkenler: Sivas merkez ilçe örneği. Anadolu Psikiyatri Dergisi, 10, 18-25.

Avşaroğlu, S., Deniz, M. E., \& Kahraman, A. (2005). Teknik öğretmenlerde yaşam doyumu iş doyumu ve mesleki tükenmişlik düzeylerinin incelenmesi. Selçuk Üniversitesi Sosyal Bilimler Enstitüsü Dergisi, 14, 115-129.

Bacanlı, F. (2012). Karar verme stratejileri ve ego kimlik statüleri arasındaki ilişkilerin incelenmesi. Eğitim ve Bilim, $37(163), 17-28$.

Balc1, A. (1985). Ĕgitim yöneticisinin iş doyumu (Doktora tezi). Ankara Üniversitesi, Ankara.

Berkant, G., H. (2017). Öğretmen adaylarının öğretmen öz-yeterlik algılarının incelenmesi. Journal of Educational Reflections, 1(2), 1-17.

Brehaut, J. C., O'Connor, A. M., Wood, T. J., Hack, T. F., Siminoff, L., Gordon, E., \& Feldman-Stewart, D. (2003). Validation of a decision regret scale. Medical Decision Making, 23(4), 281-292. https://doi.org/10.1177/0272989X03256005

Bursalığlu, Z. (2012). Okul yönetiminde yeni yapı ve davranış. Ankara: Pegem Akademi Yayıncılık.

Büyüköztürk, Ş. (2017). Sosyal bilimler için veri analizi el kitabı. Ankara: Pegem Akademi.

Çakır, M. A. (2004). Mesleki karar envanterinin geliştirilmesi. Ankara Üniversitesi Eğitim Bilimleri Fakültesi Dergisi, 37(2), 1-14.

Çakmak, M. S., \& Arabacı, İ. B. (2017). Öğretmenlerin pozitif psikolojik sermaye algılarının iş doyumları ve örgütsel bağl1lıkları üzerindeki etkisi. Elektronik Sosyal Bilimler Dergisi, 16(62), 890-909. https://doi.org/10.17755/esosder.282130

Çifçili, V. (2008). Dershane öğretmenlerinin öğretmen yeterlilik düzeyleri ve mesleki doyumları arasındaki ilişki. Hasan Ali Yücel Eğitim Fakültesi Dergisi, 10, 101-115.

Çolak, İ., Altınkurt, Y., \& Yılmaz, K. (2017). Öğretmenlerin özerklik davranışları ile iş doyumları arasındaki ilişki. Karadeniz Sosyal Bilimler Dergisi, 9(2), 189-208.

Dağl1, A., \& Baysal, N. (2016). Yaşam doyumu ölçeğinin Türkçe'ye uyarlanması: geçerlik ve güvenirlik çalışması. Elektronik Sosyal Bilimler Dergisi, 15(59), 1250-1262. https://doi.org/10.17755/esosder.263229

Demirel, H. (2014). An investigation of the relationship between job and life satisfaction among teachers. Procedia Social and Behavioral Sciences, 116, 4925-4931. https://doi.org/10.1016/j.sbspro.2014.01.1051

Demirtaş, H., \& Güneş, H. (2002). Eğitim yönetimi ve denetimi sözlüğü. Ankara: Anı Yayıncılık.

Demirtaş, Z., \& Nacar, D. (2018). Öğretmenlerin iş doyumu ve örgütsel sessizlik algıları arasındaki ilişki. Journal of Educational Reflections, 2(1), 13-23.

Diener, E. (1984). Subjective well-being. Psychological Bulletin, 95, 542-575. https://doi.org/10.1037/0033-2909.95.3.542

Diener, E., Emmons, R. A., Larsen, R. J., \& Griffin, S. (1985). The satisfaction with life scale. Journal of Personality Assessment, 49(1), 71-75. https://doi.org/10.1207/s15327752jpa4901_13

Dikmen, A. A. (1995). İş doyumu ve yaşam doyumu ilişkisi. Ankara Üniversitesi SBF Dergisi, 50(3), 115-140.

Dockery, A. M. (2004). Happiness, life satisfaction and the role of work: evidence from two Australian surveys. Unpublished Mimeo.

Durant, W., \& Durant, A. (1992). Tarihten dersler. Bozkurt Güvenç (Çev.) İstanbul: Cem Yayınevi.

Erdurcan, S., \& Kırdök, O. (2017). Mesleki karar pişmanlığı ölçeği: adaptasyon, geçerlik ve güvenirlik çalışması. Mersin Üniversitesi Eğitim Fakültesi Dergisi, 13(3), 1140-1150. http://dx.doi.org/10.17860/mersinefd.330880

Gençtürk, A., \& Memiş, A. (2010). İlköğretim okulu öğretmenlerinin öz-yeterlik algıları ve iş doyumlarının 
demografik faktörler açısından incelenmesi. İlköğretim Online, 9(3), 1037-1054.

Gergin, B. (2006). İlköğretim okulu öğretmenlerinin iş doyum düzeyleri (Yüksek lisans tezi). Gazi Üniversitesi Eğitim Bilimleri Enstitüsü, Ankara.

Gilman, R., \& Huebner, E. S. (2006). Characteristics of adolescents who report very high life satisfaction. Journal of Youth and Adolescence, 35(3), 293-301. https://doi.org/10.1007/s10964-006-9036-7

Hamamcı, Z., \& Çoban, A. E. (2007). Mesleki olgunluk ve mesleki kararsızlı̆̆ın akılcı olmayan inançlarla ilişkisi. Türk Psikolojik Danışma ve Rehberlik Dergisi, 3(27), 31-42.

Hamamcı, Z., Oskargil-Göktepe, E., \& İnanç, N. (2005). Ankara ilinde çalışan okul psikolojik danışmanlarının mesleki gelişim ve mesleki doyum düzeyleri arasındaki ilişki. Türk Psikolojik Danışma ve Rehberlik Dergisi, 3(24), 27-44.

Haybron, D.M. (2001). Happiness and the importance of life satisfaction. Department of Philosophy University of Arizona, November 20, 1-12.

İnce, N.B. (2014). Birleştirilmiş ve bağımsız sınıflarda çalışan sınıf öğretmenlerinin mesleki doyum ve tükenmişlik düzeylerinin karşılaştırılması (Yüksek lisans tezi). Hacettepe Üniversitesi Eğitim Bilimleri Enstitüsü, Ankara. https://doi.org/10.16986/HUJE.2016015702

İnce, N. B., \& Şahin, A. E. (2016). Birleştirilmiş ve bağımsız sınıflarda çalışan sınıf öğretmenlerinin mesleki doyum ve tükenmişlik düzeylerinin karşılaştırılması. Hacettepe Üniversitesi Eğitim Fakültesi Dergisi, 31(2), 391-409.

Karasar, N. (2014). Bilimsel araştırma yöntemi. Ankara: Nobel Yayınları.

Keser, A. (2005). Çalışma yaşamı ile yaşam doyumu ilişkisine teorik bakış. İstanbul Üniversitesi İktisat Fakültesi Mecmuast, 55(1), 897-913.

Khakoo, I. G. (2004). University of Michigan, Ann Arbor December 14. Quality of Life: Satısfactıon \& Its Subjective Determinants. $\quad$ Retrieved 20.04.2007 from http://www.datafirst.uct.ac.za/saproject/sa_project/workshop/spp_projects/project.imraan.khakoo.pdf

Kırcı-Çevik, N., \& Korkmaz, O. (2014). Türkiye'de yaşam doyumu ve iş doyumu arasındaki ilişkinin iki değiş̧kenli sıralı probit model analizi. Niğde Üniversitesi İ̈BF Dergisi, 7(1), 126-145.

Koruklu, N., Feyzioğlu, B., Özenoğlu-Kiremit, H., \& Aladağ, E. (2013). Öğretmenlerin iş doyumu düzeylerinin bazı değişkenlere göre incelenmesi. Mehmet Akif Ersoy Üniversitesi Ĕgitim Fakültesi Dergisi, 13(25), 119-137.

Köroğlu, Ö. (2011). Işs doyumu ve motivasyon düzeylerini etkileyen faktörlerin performansla ilişkisi: turist rehberleri üzerine bir araştırma (Doktora tezi). Balıkesir Üniversitesi Sosyal Bilimler Enstitüsü, Balıkesir.

Kumaş, V., \& Deniz, L. (2010). Öğretmenlerin iş doyum düzeylerinin incelenmesi. Marmara Üniversitesi Atatürk Eğitim Fakültesi Dergisi, 32, 123-139.

Lent, R. W., Nota, L., Soresi, S., Ginevra, M.C., Duffy, R.D., \& Brown, S.D. (2011). Predicting the job and life satisfaction of Italian teachers: test of a social cognitive model. Journal of Vocational Behavior, 79(1), 91-97. https://doi.org/10.1016/j.jvb.2010.12.006

Ma, X., \& MacMillan, R. B. (1999). Influences of workplace conditions on teachers' job satisfaction. The Journal of Educational Research, 93(1), 39-47. https://doi.org/10.1080/00220679909597627

Ordu, A. (2016). Lise öğretmenlerinin iş doyumları ve bireysel performansları arasındaki ilişki. Mustafa Kemal Üniversitesi Sosyal Bilimler Enstitüsü Dergisi, 13(36), 1-19.

Özben, Ş., \& Argun, Y. (2005). Sosyo-demografik özelliklere göre ilköğretim öğretmenlerinin iş doyumu ve tükenmişlik düzeylerinin incelenmesi. Dokuz Eylül Üniversitesi Buca Eğitim Fakültesi Dergisi, 18, 27-37.

Özdevecioğlu, M., \& Aktaş, A. (2007). Kariyer bağlılığı, mesleki bağlllık ve örgütsel bağlılığın yaşam tatmini üzerindeki etkisi: iş-aile çatışmasındaki rolü. Erciyes Üniversitesi İktisadi ve İdari Bilimler Fakültesi Dergisi, $28,1-20$.

Özer, M., \& Karabulut, Ö. Ö. (2003). Yaşl1larda yaşam doyumu. Türk Geriatri Derneği, 6(2), 72-74.

Öztemel, K. (2012). Kariyer kararsızlı̆̆ ile mesleki karar verme öz yetkinlik ve kontrol odağı arasındaki ilişkiler. GEFAD, 32(2), 459-477.

Recepoğlu, E. (2013). Öğretmen adaylarının yaşam doyumları ile öğretmenlik mesleğine ilişkin tutumları arasındaki ilişkinin incelenmesi. Hacettepe Üniversitesi Ĕgitim Fakültesi Dergisi, Özel Sayl(1), 311-326. 
Recepoğlu, E., \& Ülker-Tümlü, G. (2015). Üniversite akademik personelinin mesleki ve yaşam doyumları arasındaki ilişkinin incelenmesi. Kastamonu Ĕ̈itim Dergisi, 23(4), 1851-1868.

Sağır, M. (2016). Sınıfta motivasyon süreci. In T. Argon \& Ş. S. Nartgün (Ed.), Sinıf yönetimi'nin içinde (s. 121-148). Ankara: Maya Akademi.

Sarıkaya, T., \& Khorshid, L. (2009). Üniversite öğrencilerinin meslek seçimini etkileyen etmenlerin incelenmesi: üniversite öğrencilerinin meslek seçimi. Türk Eğitim Bilimleri Dergisi, 7(2), 393-423.

Serin, N. G., \& Özbulak, B. (2006). Okul idarecilerinin duygusal zekâ beceri düzeyleri ile yaşam doyumunu yöneticilik deneyimleri ve cinsiyet açısından incelenmesi. Uluslararası Duygusal Zekâ ve İletişim Sempozyum Bildiri Kitabı (s.23-30) içinde. İzmir, Türkiye: Ege Üniversitesi İletişim Fakültesi.

Şahin, C., \& Ada, Ş. (2013). İlköğretim ile ortaöğretim okullarında sosyal sermayenin kullanılma düzeyinin okul yöneticilerinin görüşleri doğrultusunda incelenmesi. Mustafa Kemal Üniversitesi Sosyal Bilimler Enstitüsü, 10(23), 131-153.

Şahin, H., \& Dursun, A. (2009). Okul öncesi öğretmenlerinin iş doyumları: Burdur örneği. Mehmet Akif Ersoy Üniversitesi Ĕ̈itim Fakültesi Dergisi, 18, 160-179.

Taşdan, M., \& Tiryaki, E. (2008). Özel ve devlet ilköğretim okulu öğretmenlerinin iş doyumu düzeylerinin karşılaştırılması. Eğitim ve Bilim, 33(147), 54-70.

Telef, B. B. (2011). Öğretmenlerin öz-yeterlikleri, iş doyumları, yaşam doyumları ve tükenmişliklerinin incelenmesi. İlkögretim Online, 10(1), 91-108.

Toker, B. (2006). Konaklama işletmelerinde işgören motivasyonu ve motivasyonun iş doyumuna etkileri- İzmir'deki beş ve dört ylldizlı otellere yönelik bir uygulama (Doktora tezi). Dokuz Eylül üniversitesi Sosyal Bilimler Enstitüsü, İzmir.

Yaramış, M., \& Çınkır, Ş. (2014). Ankara Üniversitesi'nde çalışan kadrolu idari personelin iş doyumu ile örgütsel bağlılı̆̆ın ilişkisi. Mehmet Akif Ersoy Üniversitesi Eğitim Fakültesi Dergisi, Sayı(31), 42-66.

Yazılıtaş, F. (2010). İlköğretim sinıf öğretmenlerinin öğrencileri motive etme düzeyleri ile mesleki doyumları arasindaki ilişkinin incelenmesi: Kayseri ili örneği (Yüksek lisans tezi). Erciyes Üniversitesi Sosyal Bilimler Enstitüsü, Kayseri.

Yılmaz, E., \& Altınok, V. (2009). Okul yöneticilerinin yalnızlık ve yaşam doyum düzeylerinin incelenmesi. Kuram ve Uygulamada Eğitim Yönetimi, 15(3), 451-469.

Yılmaz, E., \& Aslan, H. (2013). Öğretmenlerin iş yerindeki yalnızlıkları ve yaşam doyumları arasındaki ilişkinin incelenmesi. Pegem Ë̆itim ve Öğretim Dergisi, 3(3), 59-69. https://doi.org/10.14527/C3S3M6

Yılmaz, E., \& Sünbül, A. M. (2009). Öğretmenlerin yaşam doyumları ve okullardaki örgütsel güven düzeyi. Journal of Qafqaz University an International Journal Social Science, 26, 172-179.

Yılmaz, K. (2012). İlköğretim okulu öğretmenlerinin iş doyumu düzeyleri ile örgütsel vatandaşlık davranışları arasındaki ilişki. Anadolu Journal of Educational Sciences International, 2(2), 1-14.

Weiss, D. J., Dawis R. V., England, G. W., \& Lofquist, L. H. (1967). Manual for the Minnesota Satisfaction Questionnaire. $\quad$ Retrieved 12.01 .2013 from https://www.psych.umn.edu/psylabs/vpr/pdf_files/Monograph\%20XXII\%20-\%20Manual\%20for\%20the\%20M N\%20Satisfaction\%20Questionnaire.pdf

https://dulkadiroglu.meb.gov.tr/, Erişim Tarihi: 26/02/2018

http://onikisubat.meb.gov.tr/, Erişim Tarihi: 26/02/2018 